\title{
Implementation of Business Intelligence for Sales Data Management Using Interactive Dashboard Visualization in XYZ Stores
}

\author{
$1^{\text {st }}$ Ricky Akbar \\ Information System \\ University of Andalas \\ rickyakbar@,fti.unand.ac.id
}

\author{
$2^{\text {nd }}$ Meza Silvana \\ Information System \\ University of Andalas \\ meza_silvana@,ft.unand.ac.id \\ $4^{\text {th }}$ Miftahul Jannah \\ Information System \\ University of Andalas \\ m jannah06@yahoo.com
}

\begin{tabular}{c}
$3^{\text {rd }}$ Mohammad Hafiz Hersyah \\
Computer Engineering \\
University of Andalas \\
mhafiz@, fti.unand.ac.id \\
\hline
\end{tabular}

\begin{abstract}
Data Management is one of the crucial processes carried out at XYZ Store to get information about the sale of products. In carrying out its operational activities, XYZ Store uses the Smile Invent application to manage data on products sales transactions. Still, this application has not been able to assist managers in producing the required reports. Therefore, one way to overcome this problem is by implementing the Business Intelligence (BI) application at the XYZ Store by using Interactive Dashboard Visualization. In implementing the BI application, the BI Roadmap is used as a basis for conducting research starting from the identification of problems to be selected. After that, the planning phase is carried out by evaluating the infrastructure and planning projects. Then the analysis phase focuses on carrying out a detailed analysis of business problems and opportunities from BI implementation. Next is the design phase by carrying out the data warehouse design process and ETL using the Pentaho Data Integration (PDI). Then the implementation phase is carried out, namely the selection and use of BI application tools to perform Data Visualization. It is hoped that this research can produce reports in the form of Interactive Dashboard Visualization that can be used by store managers to make better decisions.
\end{abstract}

Keyword-Business Intelligence, Sales Data Management Interactive Dashboard Visualization

\section{INTRODUCTION}

In running a business, data management is a necessary process that must be carried out by companies. With proper data management, users can get added value, such as valid information to support the decision-making process that can increase effectiveness and efficiency in operations. XYZ Store is a store that is engaged in the sale of daily necessities. This store has used the Smile Invent application to process data management for products, employees, and transactions that occur every day, but this application has not been able to help managers make better decisions because the reports generated do not match their needs. The Smile Invent application manages more than 20,000 item data and approximately 563,974 sales transactions over the past three years. One way that can be done to handle this massive data is by implementing a Business Intelligence (BI) application.

$\mathrm{BI}$ is a tool for amplifying, analyzing, and visualizing big data to help management make decisions. The main focus of this BI system is on reporting, data retrieval (querying), and data analysis contained in the company's data warehouse [1]. BI consists of 5 components, namely Data Source, ETL (Extract, Transform, Load), Data Warehouse, Interactive Dashboard, and Reports. [2]. BI's goal is to help decisionmakers get the right information and make the right decisions to manage the business [3]. BI also has several advantages in its use, including first, eliminating jobs based on assumptions [4] because BI can provide more accurate historical data. Second, it helps identify business opportunities by making trends in market conditions [5]. Third, it helps in understanding consumer behavior [6]. Fourth, it helps create realistic goals [7]. Fifth, help identify opportunities for crossselling and up-selling [8]. And the sixth increases efficiency [9].

Of the various advantages and benefits of implementing BI, of course, it can help companies in the data management process to produce better data visualization and reporting, which is useful for decision making and improving services for the company's business. In addition, implementing BI there are also various challenges, among others; limited knowledge on how BI analytics can support production goals, limited interest from executives and owners on how to use BI as a decision support and lack of skills to use BI analytics in general [15]

\section{METHODOLOGY AND BUSINESS INTELLIGENCE DESIGN}

The method in this research consists of data collection methods and methods in implementing BI applications adopting the BI Roadmap.

\section{A. Data Collection Methods}

The types of data collected are primary and secondary data. Primary data is data that is collected directly from the object under study, namely data on products and sales of products. This data is obtained directly from the database used in the company products data management application. Figure 1 is a snippet of sales data sources obtained from the Smile Invent application database used by the company. 


\begin{tabular}{|c|c|c|c|c|c|c|c|c|c|c|}
\hline & $\nabla$ & location & customer_id & customer & employee_id employee & document_id & $\begin{array}{r}\text { invoice_numbers } \\
-1\end{array}$ & date & product_id & product_name \\
\hline • ¿ Copy & () Delete & ТОКО & 1 & $\begin{array}{l}\text { CUSTOMER } \\
\text { CASH/KONTAN }\end{array}$ & 1 & $1401 J 100001$ & 1400001 & 2014-01-01 & 1923161 & $\begin{array}{l}\text { XL } \\
\text { PROFESSIONNEL } \\
\text { HAIR SERUM }^{\star}\end{array}$ \\
\hline ¿ Copy & () Delete & TOKO & 1 & $\begin{array}{l}\text { CUSTOMER } \\
\text { CASH/KONTAN }\end{array}$ & 1 & 1401J100001 & 1400002 & 2014-01-01 & 990284 & $\begin{array}{l}\text { MAKARIZO HAIR } \\
\text { ENERGY SACHET } \\
60 \text { GR }^{*}\end{array}$ \\
\hline • Copy & (-) Delete & TOKO & 1 & $\begin{array}{l}\text { CUSTOMER } \\
\text { CASH/KONTAN }\end{array}$ & 1 & $1401 \mathrm{~J} 100002$ & 1400003 & 2014-01-01 & 51815 & $\begin{array}{l}\text { CAR.REFIL DAC } \\
\text { EP 03 IVORY } \\
\text { BEIGE }\end{array}$ \\
\hline - Copy & (-) Delete & TOKO & 1 & $\begin{array}{l}\text { CUSTOMER } \\
\text { CASH/KONTAN }\end{array}$ & 1 & $1401 J 100002$ & 1400004 & 2014-01-01 & 11282 & $\begin{array}{l}\text { REVLIP GLOSS } \\
\text { SLLALL }\end{array}$ \\
\hline ¿ Copy & () Delete & TOKO & 1 & $\begin{array}{l}\text { CUSTOMER } \\
\text { CASH/KONTAN }\end{array}$ & 1 & $1401 \mathrm{~J} 100003$ & 1400005 & 2014-01-01 & 490096 & $\begin{array}{l}\text { MAYLIP COLOR } \\
\text { SEN ALL }\end{array}$ \\
\hline • ¿ Copy & (-) Delete & TOKO & 1 & $\begin{array}{l}\text { CUSTOMER } \\
\text { CASH/KONTAN }\end{array}$ & 1 & 1401J100004 & 1400006 & 2014-01-01 & 401002 & $\begin{array}{l}\text { AU.POWDER } \\
\text { FOUND. } 02 \\
\text { PORCELAIN }\end{array}$ \\
\hline ¿ Copy & (-) Delete & TOKO & 1 & $\begin{array}{l}\text { CUSTOMER } \\
\text { CASH/KONTAN }\end{array}$ & 1 & $1401 \mathrm{~J} 100005$ & 1400007 & 2014-01-01 & 996532 & $\begin{array}{l}\text { COT BUD COTTA } \\
\text { POLIBAG NEW } \\
100\end{array}$ \\
\hline ¿ Copy & () Delete & TOKO & 1 & $\begin{array}{l}\text { CUSTOMER } \\
\text { CASH/KONTAN }\end{array}$ & 1 & 1401J100005 & 1400008 & 2014-01-01 & 996423 & $\begin{array}{l}\text { SISIR MEDAL } \\
\text { TWC } 002^{*}\end{array}$ \\
\hline ¿' Copy & Delete & TOKO & 1 & $\begin{array}{l}\text { CUSTOMER } \\
\text { CASH/KONTAN }\end{array}$ & 1 & $1401 \mathrm{~J} 100005$ & 1400009 & 2014-01-01 & 9962138 & $\begin{array}{l}\text { BIORE NEW } \\
\text { FACIAL FOAM } 40^{*}\end{array}$ \\
\hline ¿ Copy & () Delete & TOKO & 1 & $\begin{array}{l}\text { CUSTOMER } \\
\text { CASH/KONTAN }\end{array}$ & 1 & $1401 \mathrm{~J} 100005$ & 1400010 & 2014-01-01 & 996658 & $\begin{array}{l}\text { SISIR MEDAL MC } \\
61\end{array}$ \\
\hline
\end{tabular}

Fig 1. Sales Transaction Data Source

While secondary data is data collected through reference books related to the study of the problem under review, interviews, and observations.

a. Observation

Observations are made by observing the flow of the sales system and software used to manage products and sales data.

b. Interviews

Interviews aim to obtain more detailed and definite information about the research being carried out. Interviews were conducted by asking questions to the sales data manager admin.

c. Study of Literature

Literature studies are carried out by studying literature sourced from internet sites, scientific journals, and other readings.

\section{B. Methodology of Implementing BI Application}

The method used in implementing the BI application was adopted from the BI Project Life Cycle. The phases contained in the BI Project Life Cycle are: 1). justification phase, this phase discusses the business case assessment, which is the first step into consideration for users developing $\mathrm{BI}, 2)$. the planning phase, this phase presents two main activities, namely enterprise infrastructure evaluation and project planning, 3). business analysis phase, in this phase, the Project Requirement Definition, Data analysis, Application Prototyping, and Metadata Repository Analysis are carried out, 4). the design phase, in this phase, the database design, ETL (Extract, Transform, Load) design, and metadata repository design is carried out, 5). Construction, the stages carried out in this phase are ETL development, application development, data mining, and metadata repository development, and 6). In the deployment phase, this phase is implementation and release evaluation. These phases must be worked out in sequence. BI Project Life Cycle can be seen in Figure 2.

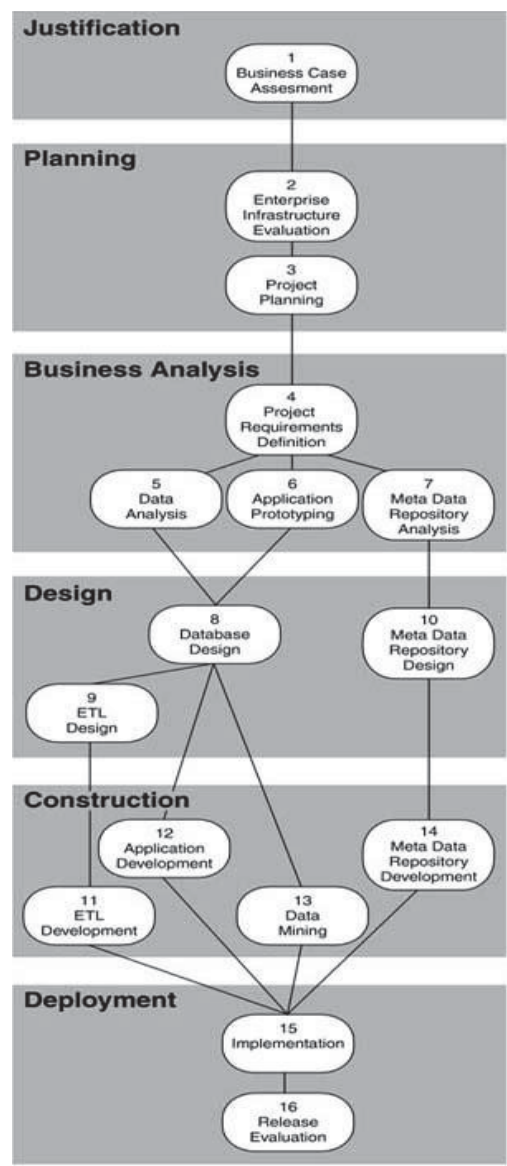

Fig 2. BI Project Life Cycle [10]

\section{Business Intelligence Design}

Before implementing the BI application used, a BI design is first carried out consisting of a Data Warehouse Architecture design and an ETL (Extract-Transform-Loading) design.

Data warehouse is a collection of data that is integrated, subject-oriented, time-variant, and nonvolatile that can support management decision making [11]. Also, a data warehouse is a place to store summaries of historical data, which are often retrieved from separate databases [12]. 


\section{1) Data Warehouse Characteristics}

Data warehouse has specific characteristics so that it can be distinguished from other data. Attributes of a data warehouse [11] namely:

1. Subject-oriented

The nature of a subject-oriented data warehouse means that the data warehouse is designed to analyze data based on a specific subject-oriented organization or company, not on a particular application process or function.

2. Integrated

The nature of an integrated data warehouse means that the data warehouse can store data originating from separate sources into a fixed format and is combined with one another.

3. Time-Variant

The nature of the data warehouse has a period, which means that all data in the data warehouse can be said to be accurate at a particular period.

4. Nonvolatile

The nature of a nonvolatile data warehouse means that the data in the data warehouse is not updated in real-time but is refreshed from the operating system regularly.

\section{2) Data Warehouse Dimensional}

Data warehouse dimensional model is a design that aims to display data in the form of a relationship model between entities [11]. Each dimension table has a simple primary key. A primary key in a fact table consists of two or more foreign keys. This characteristic structure is modeled in a star schema or snowflake schema. The following is an explanation of the fact table and dimension table [13]:

1. Fact Table

Fact table is the main table that stores transaction values in the form of numeric data and key attributes. The transaction value is the value that saves business performance, and the key attribute is the attribute refers to the dimension table.

2. Dimension Table

The dimension table is a reference table or descriptive table that complements and explains the key attributes of the fact table.

The dimensional model has several schematic structures. Some forms of data warehouse schema structure, namely [14] namely :

1. Star schema

Logical structures that have fact tables containing fact data in the middle position, surrounded by dimension tables containing reference data.

2. Snowflake schema

The snowflake schema is a variant of the star schema, and dimension tables do not contain denormalized data.

\section{3) Designing Data Warehouse Architecture}

In the design, the data warehouse that is built must define how the architecture and modeling of the data warehouse will be. This data warehouse architecture design is in the form of logical and physical architectures. Logical architecture is the design of the stages of data flow from the data source used to the data warehouse used to create BI reports. Physical structure is a technical description of the configuration applied to the data warehouse. This logical and physical architectural design can be seen in Figures 3 and 4 .

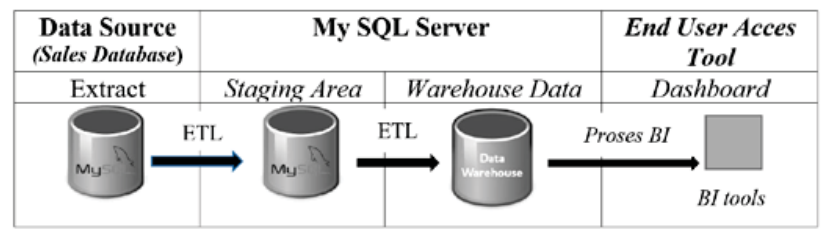

Fig 3. Logical Data Warehouse Architecture

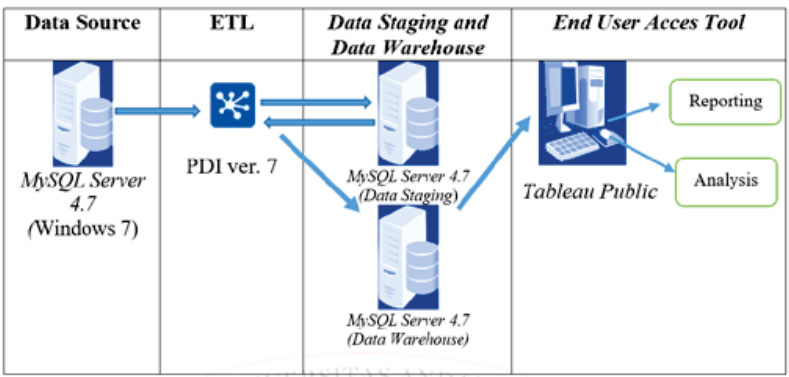

Fig 4. Physical Data Warehouse Architecture

\section{4) Data Warehouse Schematic Design}

Before designing a Data Warehouse Scheme, identification of the tables in the database will be made into Dimensional Tables and Facta Tables. Dimension table has detailed information on the dimension attribute from the fact table. Besides, the dimension table is attached to the fact table. Each dimension table stores different information as required by the fact table. The dimension table in the sales data warehouse, in this case, consists of 6 dimension tables, namely the dimension table for type, brand, status, employee, product, and time. After the dimension table is formed, a fact table is created. The fact table created has computable data. This is useful for displaying charts on the dashboard visualization process. The fact table, in this case, has 1 table, namely the sales fact table. So based on the identification that has been done, a relationship scheme is formed that forms a data warehouse. The schematic design used is the snowflake scheme. The reason for using this scheme is because of the dimension table that is related to other dimension tables in the source data. The advantages of this scheme include taking up fewer data storage space. In addition, the structure is more flexible to update and maintain. Snowflake Schematic Data Warehouse design can be seen in Figure 5. 


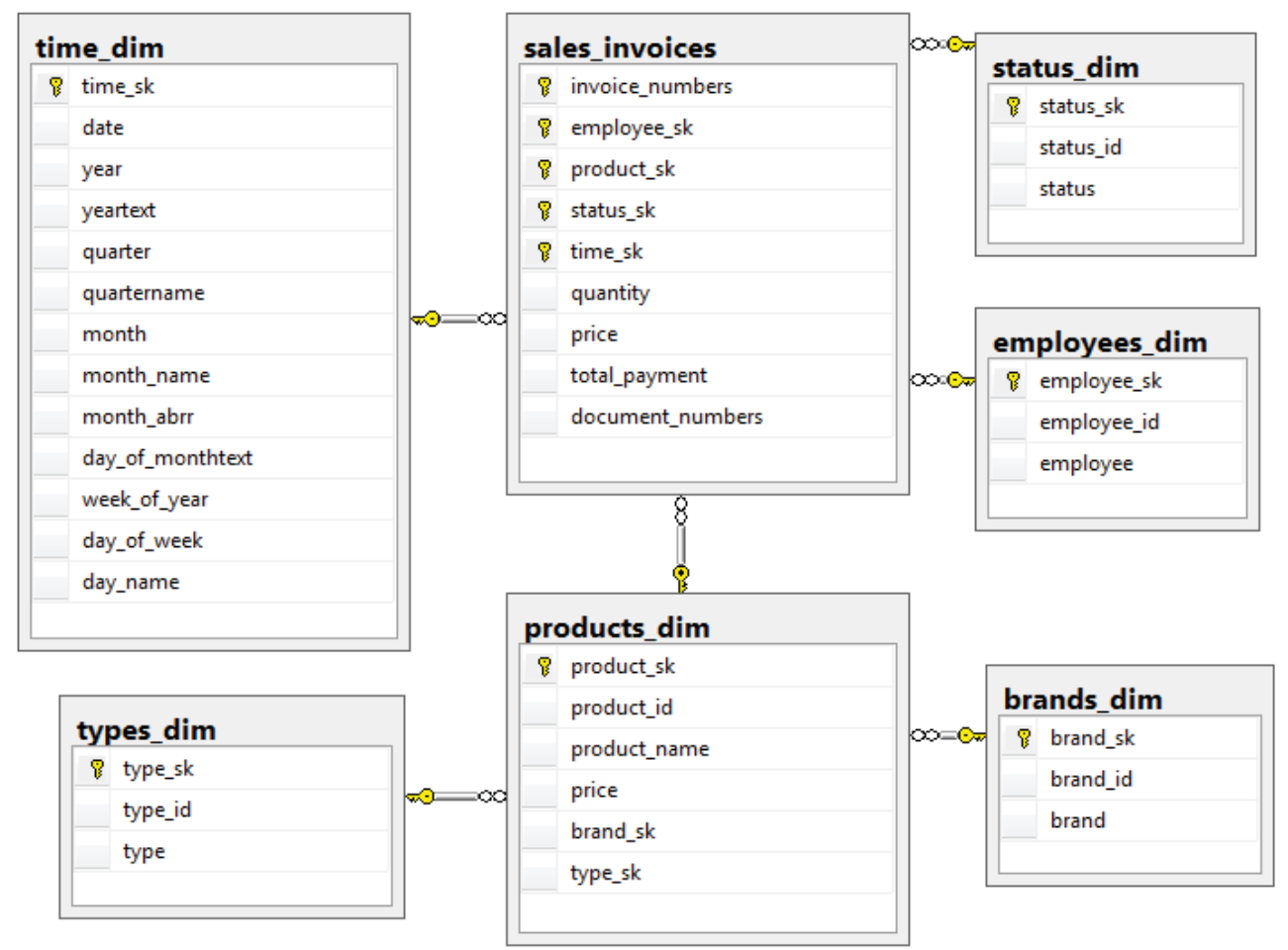

Fig 5. Snowflake Schema Data Warehouse Design.

\section{5) ETL Process (Extract-Transform-Loading)}

The ETL process is a process that consists of inputting data from an operational database or staging data into a data warehouse. This process uses the Pentaho Data Integration (PDI) tool. The ETL process is carried out based on the logical and physical architectural design of the data warehouse
Previous. In this case, the ETL process was carried out for six dimension tables and one fact table that had been selected and selected based on the staging data (data source) earlier. The following is an example of the results of the Product Dimension data ETL process, as shown in Figure 6.

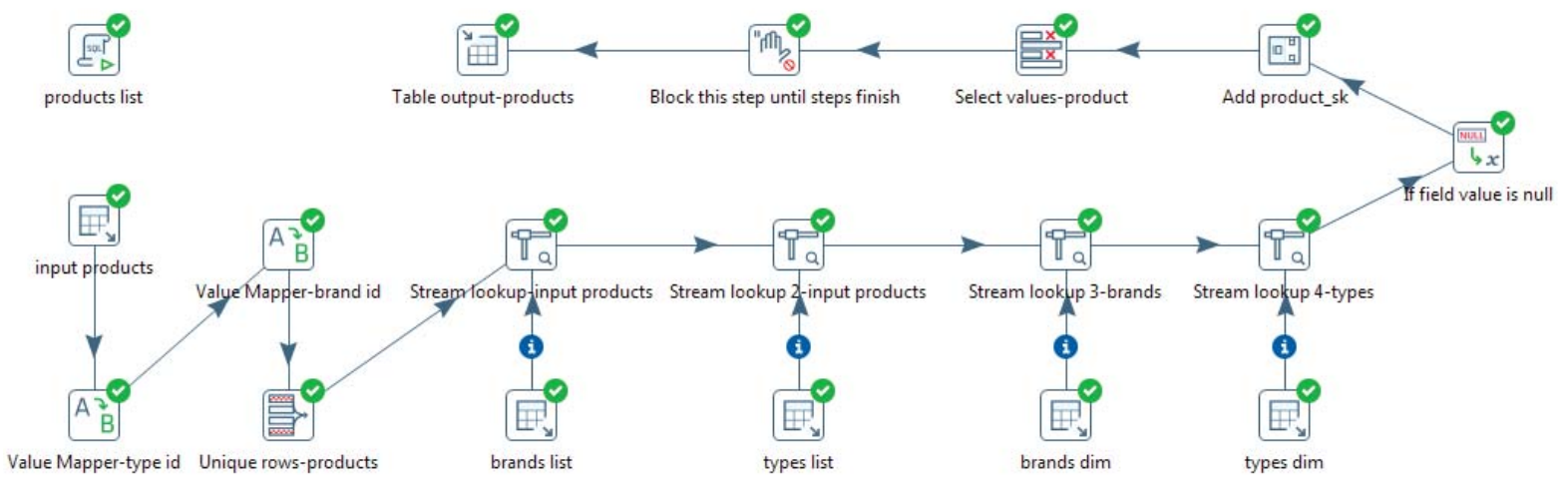

Fig 6. ETL Product Dimensions Design and Execution

Based on Figure 6, for designing the ETL process, the Product Dimensions table is taken from the staging data so that it can produce records against the dim_product table. After that, the process that is carried out is imported into the dim product table. In making product dimensions, a new id named sk product is added as the surrogate key, and a unique row tool is added to ensure that no duplicate product id data is entered into the product dimension table. In addition, the value mapper tool for id_brand and id tipe is also added, which functions to replace duplicate data in the product dimension table. The same steps are also carried out for the other 5 dimension tables, namely the brand dimension, the type dimension, the status dimension, the employee dimension and the type dimension. After that, the ETL design was carried out for the sales fact table. The design results of the ETL sales fact table process can be seen in Figure 7. 


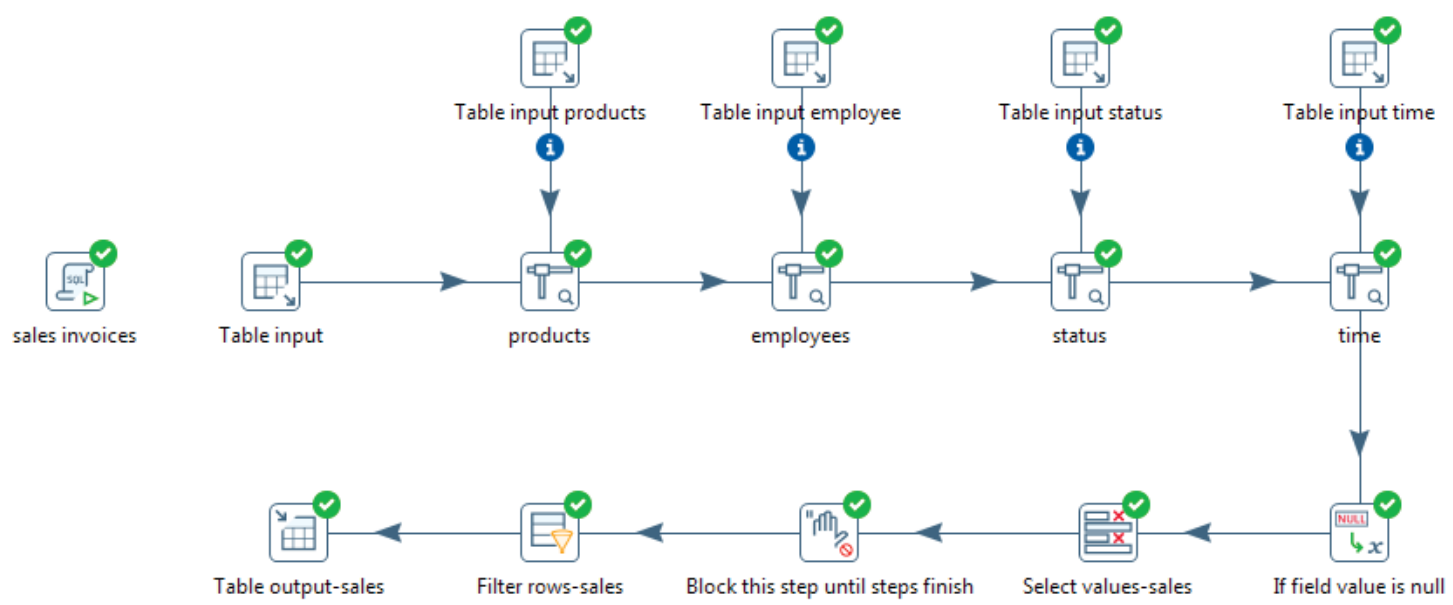

Fig 7. ETL Sales Facts Design and Execution

Based on Figure 7, the ETL design results from the sales fact table can be explained that the sales fact table accommodates the primary key dimensions and has a measurement. In making the sales fact table, filter rows are carried out by selecting data with sk produk, sk_status, sk_pegawai, price, amount, total_bayar to be equal to 0 to get the accuracy of the data in the fact table.

\section{IMPLEMENTATION AND VISUALIZATION}

This implementation stage is carried out after completing the Data Warehouse design and ETL Process. Implementation is done using the Public Tableau Tool to visualize data in the form of dashboards and charts. Based on the design of the data warehouse and the ETL process, it produces a visualization in the form of 1 dashboard, namely a dashboard of sales of products and 11 graphs that are tailored to the desired functional needs. The 11 forms of graphic visualization, among others :

1. Graphic visualization of products sold (drill-down)

2. Visualization of most customer charts (day, month and year)

3. Graphic visualization of the number of products sold by the brand
4. Graphic visualization of the number of items sold by type

5. Graphic visualization of the number of products sold based on the document number

6. Graphic visualization of sales of products by quantity

7. Graphic visualization of the most expensive sold items per year

8. Graphic visualization of total annual sales

9. Visualization of sales charts by brand

10. Graph visualization of total sales by type

11. Graphic visualization of products sold by yearly invoice number

\section{A. Products Sales Dashboard}

Products Sales Dashboard is a collection of visualizations of various charts that have been created. It aims to collect sales information in one place. Based on the Dashboard of products sales for three years, the sample data were taken, namely 2014, 2015, and 2016, experienced a decrease in total sales so that it gave a decreasing sales trend on the chart. The form of sales dashboard display can be seen in Fig 8.
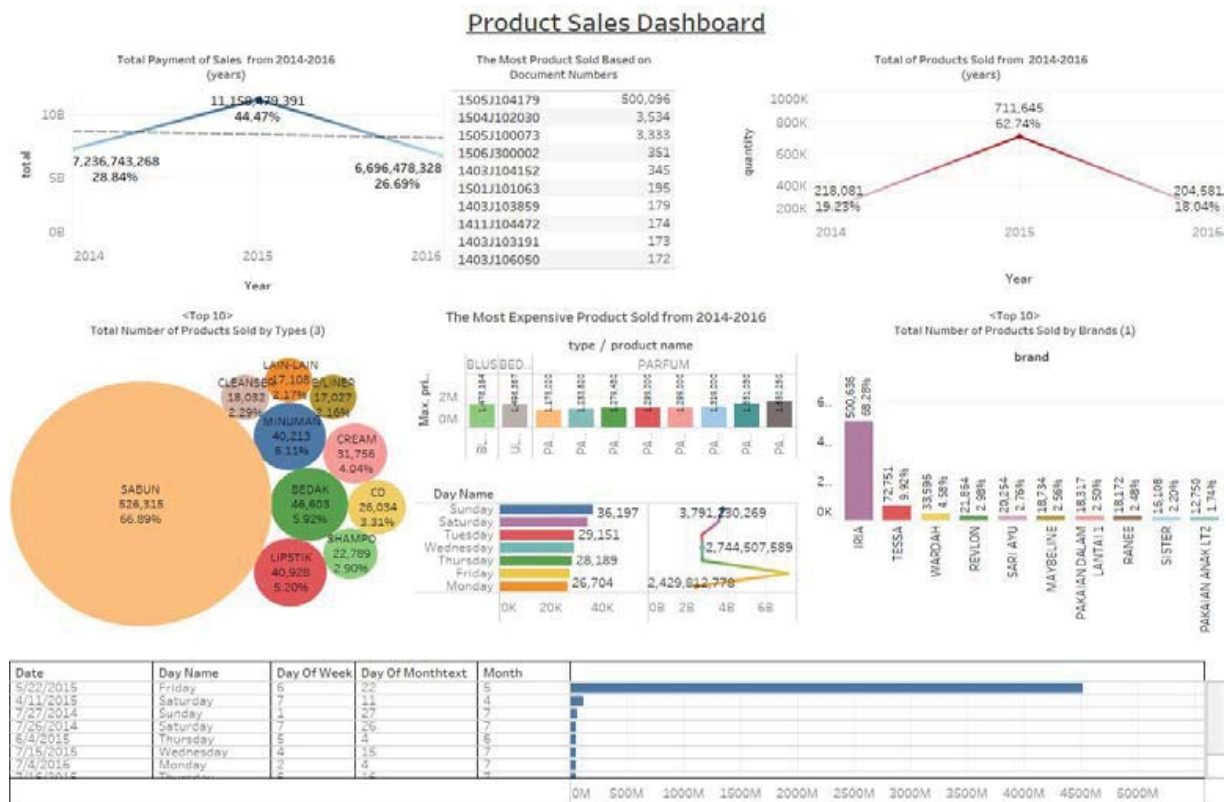

Fig 8. Products Sales Dashboard 
B. Graphic Visualization

Graphic visualization is a detailed part of the Dashboard that has been created. The following describes some graphic visualizations based on the sales dashboard:

1. Graph for Total of The Most Product Sales Based on Brands (Top 10).

The graph of total sales by brand of products was taken as the data sample from 2014-2016. Based on the data trend in the chart, it shows that the highest complete sales transactions were Rp 4,509,929,090 with the Iria products brand. The total sales of this brand of products far exceeded that of other brands such as the Revlon, Wardah, Imported Perfumes, and other brand products, which only had a house of around Rp. 1 billion. For detailed data visualization of the top 10 total sales by brand can be seen in Figure 9.

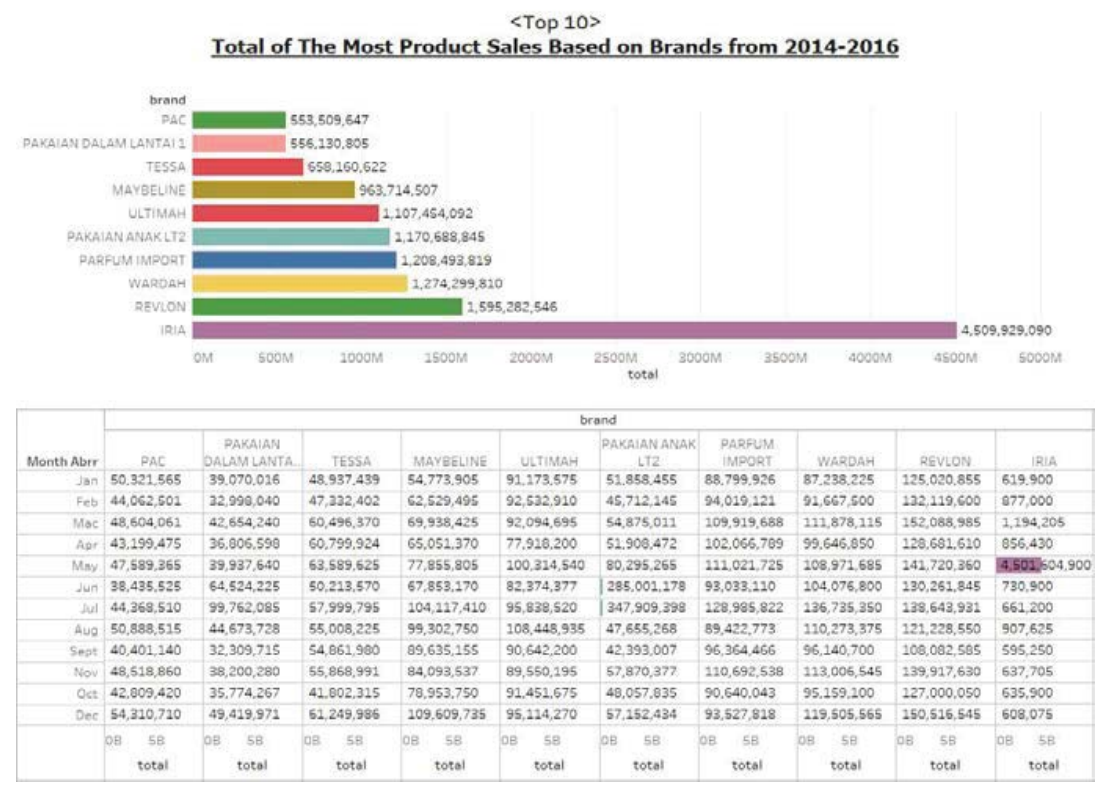

Fig 9. Graph for Total of The Most Product Sales Based on Brands form 2014 to 2016

2. Graph for Total Number of Products Sold by Types (Top 10).

The graph of the number of products sold based on the type of the sample data for 2014-2016 shows that the highest sales occurred in the type of products Soap with the number of products sold 526,315. This type of item far exceeds other brands such as Powder, Beverage Lipstick, and different kinds of things, which are only around tens of thousands of items. For details on the data visualization of the Top 10 Total Items Sold by Type can be seen in Figure 10.

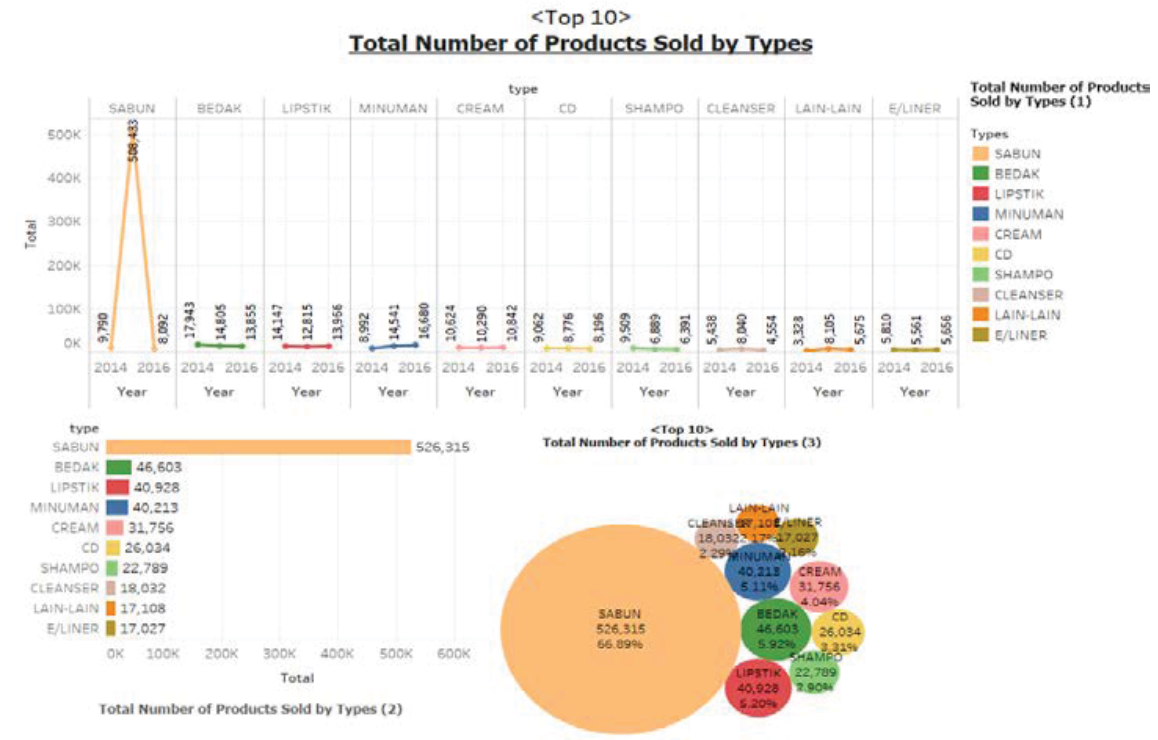

Fig 10. Graph for Total Number of Products Sold by Types 
3. Graph for Total of Products Sold from Based on Quantity

The graph of the number of products sold based on the quantity from the sample data for 2014-2016 shows that there were a total of 1,134,307 items recorded. Most sales occurred in 2015, with around 711,645 items sold.
After that followed in 2014 as many as 218,081 units and in 2016 as many as 204,581 units. For detailed data visualization on the number of products sold can be seen in Fig 11.

\section{Total of The Products Sold from 2014-2016}

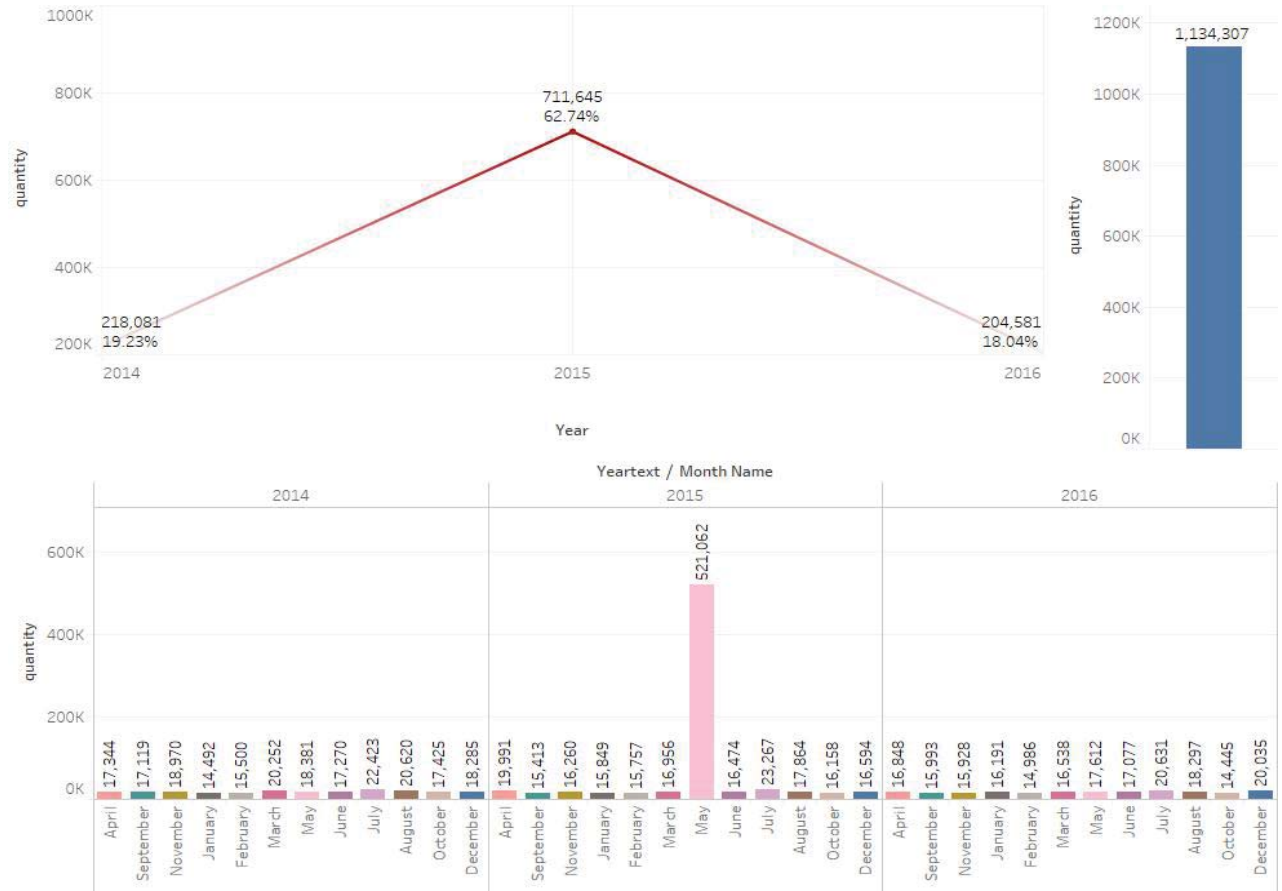

Fig 11. Graph for Total of Products Sold from 2014 to 2016 Based on Quantity

\section{CONCLUSION}

Application of Business Intelligence (BI) for sales data management using Interactive Dashboard Visualization can be built by doing BI Design first, namely, 1). Data warehouse architectural design consisting of logical and physical designs, 2). ETL process using the Pentaho Data Integration (PDI) tool. After this process is done, the next step can be visualized data using the Public Tableau Tool in the form of a System Dashboard and Graphic Visualization. Based on the case of this XYZ store, there is 1 Dashboard, namely Sales Dashboard and 11 Graphic Visualizations, according to the needs of the company.

\section{ACKNOWLEDGMENT}

This Research is Supported by Faculty of Information Technology, University of Andalas, Padang-Indonesia for Publication

\section{REFERENCE}

[1] Euis Nina Saparina Yuliani, Heru Subawanto, Anggi Oktaviani. (2017). "Business Intelligence Dashboard Implementation on a Travel Agency in Jakarta". International Journal of Advanced Engineering Research and Science (IJAERS).Vol-4, Issue-6, Jun- 2017. ISSN: 2349-6495(P) | 2456-1908(O).

[2] Wajong, A. M. R. : Business intelligent system to make management decision in project management. International Information Institute (Tokyo).Information, 18(8), 3353-3360. (2015).

[3] Pourshahid, A., Johari, I., Richards, G., Amyot, D., \& Akhigbe, O. S. : A goal-oriented, business intelligencesupported decision-making methodology. Decision Analytics, 1(1), 1. (2014).

[4] Ranjan, J. : Business intelligence: Concepts, components, techniques and benefits. Journal of heoretical and Applied Information Technology, 9(1), 60-70. (2009). 
[5] El Deen, M. A., \& Solayman, M. M. : Maximizing strategic performance results: Adopting balanced scorecards and BI tools. International Journal of Computer Applications, 117(10) (2015).

[6] Chen, H., Chiang, R. H., \& Storey, V. C. : Business Intelligence and Analytics: From Big Data to Big Impact. MIS quarterly, 36(4), 1165-1188. (2012).

[7] Kasem, M., \& Hassanein, E. E. : Cloud business intelligence survey. International Journal of Computer Applications, 90(1) (2014).

[8] Bose, R. : Advanced analytics: Opportunities and challenges. Industrial Management \& Data Systems, 109(2), 155-172. (2009).

[9] Trkman, P., McCormack, K., De Oliveira, M. P. V., \& Ladeira, M. B. : The impact of business analytics on supply chain performance. Decision Support Systems, 49(3), 318-327. (2010).

[10] LT Moss and S. Atre. (2003). Business Intelligence Road Map : The Complete Project LifeCycle For Decission Support Application. Boston: MA. Addison Wesley.

[11] W. Inmon, Building the Data Warehouse 4th Edition, Wiley Publishing, Inc: Indianapolis, Indiana, 2005.

[12] Ralph Kimbal and Joe Caserta, The Data Warehouse ETL Toolkit, Indianapolis: Wiley Publishing Inc, 2004.

[13] I. Kamil, D. Novianto, M. Susanti, B. Rahmat, N. Lasmana, E. Tantrisna dan R. I. Delfiani, "Data Warehouse Model and Data Mart to Support Executive Decision Making," Postgraduate Programme, 2014.

[14] P. Ponniah, Data Warehouse Fundamental for IT Proffesionals, second edition penyunt, New York: Jhon Willy and Sons, Inc, 2001.

[15] K. Gudfinnsson and M. Strand "Challenges With BI Adoption in SMEs". 8th International Conference on Information, Intelligence, Systems \& Applications (IISA)". 2017 